\title{
THE IMPORTANCE OF INTELLECTUAL PROPERTY IN BUSINESS
}

\author{
Juna Kjaksta1, Kristaps Gailis ${ }^{2}$ \\ ${ }^{1} \mathrm{Mg}$. iur, lecturer, Rezekne Academy of Technologies, Rezekne, Latvia, \\ e-mail: Juna.Kjaksta@rta.lv \\ ${ }^{2} \mathrm{Mg}$. iur, lecturer, Rezekne Academy of Technologies, Rezekne, Latvia, \\ e-mail: kristaps.gailis@rta.lv
}

\begin{abstract}
The search for a balance of interests of right holders and users, legal means for the exclusive rights enforcement in the conditions of the development of new technologies, the problems of protection of intellectual property are considered in the paper. At the present time intellectual property is considered to be one of the most valuable assets of a business. Possessors of rights can secure their loans using their intellectual property as collateral. The authors claim that the Latvian legal and regulatory framework does not cover essential issues. The aim of the research is to explore and identify the importance of intellectual property rights in business. The following tasks were set to achieve the aim: to explore the theoretical aspects of intellectual property rights, to identify possibilities for intellectual property development in business. The following scientific research methods are used in the paper: the development of intellectual property rights in commercial law is investigated with the help of the descriptive method; the systemic method is used to analyse national legal norms in conjunction with international documents and recommendations; the comparative method has been used to study models of intellectual property rights.
\end{abstract}

Keywords: exclusive rights, intellectual property rights, piracy, plagiarism. JEL code: $034, K 11$.

\section{Introduction}

It is customary to talk about intellectual property (IP) as the result of a person's mental activity. Intellectual property includes inventions, literary and artistic works, projects and symbols, names and images used in commercial activities. Legal protection of intellectual property is provided by patent, copyright, industrial designs and trademarks. These tools allow authors to get recognition or benefit financially from their creativity, giving them certain rights, which establishes the use of the results of the author's thoughts by third parties (Pētersone, 2013). The relevance of intellectual property lies in the fact that information technology transforms the structure of modern production and distribution, significantly affects labour productivity, becomes the basis of enterprise competitiveness, and is an indicator of the viability of production.

Research novelty: The importance of material property in business was analysed by numerous studies of law scientists, but only a few studies are devoted to the analysis of intellectual property. The topicality of intellectual property in entrepreneurship could be on the theoretical plate, 
especially considering that in Latvian law, intellectual property issues from the point of view of commercial law have not been the subject of extensive and in-depth research so far.

Research period: $2017-2019$.

Research aim: To explore and identify the importance of intellectual property rights in business.

Research tasks: To explore the theoretical aspects of intellectual property rights, to identify possibilities for intellectual property development in business.

Research methods: the descriptive method, the systemic method, the comparative method.

Research hypothesis: In today's economy, innovation management requires a good knowledge of the intellectual property rights system to ensure that the company maximises its innovation and creativity, establishes profit-making partnerships and avoids unauthorised use of intellectual property belonging to another person.

The ability to exploit the economic values related to the work or other subject matter is important for the right holder of protected material. Some protected material, such as literary works, phonograms or computer software, can be copied and reproduced relatively easily. Moreover, the growth of the Internet has made it possible to distribute works rapidly and extensively at little or no cost. Copyright and neighbouring rights protection is needed to ensure that the creator of a work or the right holder of other subject matter is rewarded for the exploitation of the work or other production (WIPO, 2005). By creating legal safeguards for protected material and by enforcing these protective legislative measures, laws, and legal enactments, nations can promote the development of copyright industries, turning them into important business sectors.

\section{The concept and the economic role of intellectual property}

The first international treaties in the field of intellectual property were signed about 130 years ago. They laid the international legal foundation of the intellectual property system. These agreements - the Paris Convention for the Protection of Industrial Property (adopted in 1883) and the Berne Convention for the Protection of Literary and Artistic Works (adopted in 1886) - remain key elements of the intellectual property system today (WIPO, 2014). However, the world has changed so radically that even the most daring ideas of the authors of the first treaties fade in comparison with reality. For intellectual property law to meet the needs of a digital, interdependent and global society today and in the future, it must keep pace with the times. 
In the framework of the World Intellectual Property Organization (WIPO) project, implemented in Panama, the United Republic of Tanzania, Thailand and Uganda, small farmers receive support in the use of branding strategies, in particular for trademarks and certification marks or geographical indications, to increase the income from high-quality local products. The project, implemented in Zanzibar, aims to improve the market position of the main export crops of the island - cloves and to return the country to a leading place in the export of this spice (WIPO, 2014).

Thus, intellectual property is a certain type of information that may belong to a person (or group of persons) and be used to obtain economic benefits. Considering the economic essence of intellectual property, analysing its foundations, it is worth mentioning not knowledge, which has a somewhat philosophical nature, but a more specific definition "information".

It is worth noting that information (as an object of intellectual property) has a number of features and is different from any other resource: (Philips et al., 1990)

- information resource cannot be fully used (if any information has been used, it does not mean that it cannot be used again, as the use of information does not disappear);

- information is inalienable. When selling information, the owner continues to use the information, since it is impossible to destroy it in his mind;

- information has universal separability and reproducibility;

- information can be almost freely and instantly spread over time (given the development of modern technologies, we can say that information has no boundaries of distribution);

- in the production of products that closely relate to the use of intellectual resources, for example, software, the cost structure is significantly different from the cost of production of ordinary goods. So, when creating a computer program, significant costs for the production of the first copy are significant, but at the same time, the marginal costs associated with the production (essentially copying) of subsequent units of goods are incomparably smaller.

Enterprises, universities, sports teams, artists, and non-profit organizations should be aware of the commercial value of their intellectual property, and generate revenue from the reuse of their brands, designs, artwork, or any other merchandising elements. Similarly, enterprises that sell consumer goods at low prices should consider using, subject to legal authorization, designs, copyrighted materials, characters, etc. and other companies in order to make their products even more popular and attractive (Blakeney, 2006). For successful merchandising, enterprises will need legal 
knowledge in the field of intellectual property, skills in concluding commercial contracts and negotiating.

Innovation and intellectual property are separate, but closely related concepts. Innovation often leads to the creation of intellectual property, while intellectual property rights provide tools for financing the development of innovative ideas and driving them to the market. Innovation should not be an end in itself, but should be methodically integrated into business culture and practice to improve the overall performance of companies.

To remain competitive in today's very high global competition, the company's ability to innovate is essential, and innovation in the company's overall strategy can be integrated as follows (WIPO, 2011). Although price can compete in the short term, such a policy is not sustainable in the longer term. Sustainable competitiveness requires constant innovation in both production and management. However, the ability to engage in continuous innovation requires a paradigm shift in enterprise culture. Business organisations are well suited to providing entrepreneurs with a set of skills and tools to promote sustainable innovation.

Another problem is that legislation protecting intellectual property is not yet fully developed in Latvia. Only recently have there been laws that fully cover all parts of intellectual property. One of the most negative features of the intellectual products market is piracy. The Creator of a film, book, musical work or any computer program, even in spite of copyright, is practically not immune from unlicensed copying and illegal sale of his/her work (Maskus et al., 1995). Because of this, not only the creators of the products suffer, but also the state, since taxes do not go to the budget from pirated products. This problem is caused not only by the presence of infringers of intellectual property rights, but also by the absence of the concept of plagiarism, illegal use in the public consciousness. The main task of the state in this case is not only to prosecute piracy by law, but also to inspire citizens with the idea that any violation of intellectual property rights is illegal, even if it is not committed for profit.

\section{Intellectual property in Latvian business}

According to Article 27 of the Universal Declaration of Human Rights, "everyone has the right to the protection of the moral and material interests resulting from any scientific, literary or artistic production of which s/he is the author." Although the relationship between intellectual property and human rights is a complex one, there are moral arguments for intellectual property. 
Innovative and creative ideas underlie the success of enterprises. However, the ideas themselves are not of great value. They need to be developed, turned into a new product or service and successfully marketed to enable the enterprise to benefit from innovation and creativity. In particular, intellectual property patents can be important for turning innovative ideas and inventions into competitive products that significantly increase net profits.

It is very important to understand the difference between the concepts of "invention" and "innovation". The invention is a technical solution to some technical problem. The invention can be in the form of an innovative idea, an active model or a prototype (Rammer, 2009). Innovation is the process of translating an invention into a market commodity or profitable technology. Some of the reasons why companies are engaged in innovation are:

- improving production technology to save costs or improve productivity;

- $\quad$ introducing new products that meet the needs of consumers;

- maintaining competitiveness and/or expanding market share;

- $\quad$ ensuring the development of technologies that meet the existing and future needs of entrepreneurs and their customers;

- eliminating technological dependence on the technologies of other companies (WIPO, 2006).

For most small and medium-sized enterprises, the marketing of products and services is a major challenge. The marketing strategy should establish a clear link between the products and services and the enterprise as the manufacturer or provider of such products or services. In other words, consumers should be able to distinguish at a glance between products and services and those of competitors and associate them with a certain desired quality.

Intellectual property, if used effectively, is an important tool for creating a business image in the representation of current and potential customers or for the localization of business in the market (Fawcett et al., 1998). Intellectual property rights in combination with other marketing tools (such as advertising and other promotional activities) are important in order to:

- distinguish products and services and make them easily recognizable;

- promote products and services and acquire a loyal clientele;

- diversify market strategy to suit different target groups;

- sell products and services in other countries.

According to the authors, analysing the Latvian market in the field of intellectual property, the following key provisions may allow the protection of intellectual property rights (Rozenfelds, 2004) for merchandising purposes: 
- Protection of trademarks. Registration of a trademark gives its owner the exclusive right to use the mark for certain goods and services. It is necessary to ensure that the trademark is adequately protected in respect of the goods and services concerned. For example, a bicycle shop may register its trademark in respect of bicycles and other vehicles, but if it wants to offer its brand on tshirts and caps, it is advisable for it to register the trademark also for use on clothing and hats in the countries where it plans to sell the product. It should be borne in mind that the main features of a person or fictional character may, in certain circumstances, also be considered as trademarks.

- Protection of original samples. Industrial designs are relevant in terms of protecting the decorative or aesthetic aspects of merchandising items. For example, a cartoon character can be represented in the form of aesthetic designs for toys, jewellery, dolls, brooches, pins, etc. Protection of the sample will be especially important in cases of exclusion or reduction of copyright protection (especially when the artwork was created with the purpose of industrial exploitation).

- Copyright protection. Copyright it self does not depend on official procedures. However, it is strongly recommended that works be deposited and registered with the copyright office in countries where such offices exist and that a copyright notice be placed on the works. If a copyrighted work is sold under a license for merchandising purposes, the license agreement must make it clear that the licensee must post a copyright notice each time the work is reproduced on merchandising goods.

- Intellectual property protection in all relevant markets. Intellectual property rights are territorial in nature and should be protected at the appropriate time in all potential export markets.

- Measures against violations of intellectual property rights. The owner of the intellectual property rights has the right to determine any infringement or counterfeiting of his or her intellectual property rights and to decide what action should be taken. Depending on the form of protection and legal tradition of each country, appropriate measures may be taken to prohibit illegal merchandising of intellectual property through unfair competition law, legislation on the representation of something under a false name ("passing off"), legislation on trademarks, copyright, industrial designs, personal rights, right to public use and/or protection of privacy, or similar legislation. 


\section{Conclusion and suggestions}

In the $21^{\text {st }}$ century, science and intellectual property are considered not only as the foundation and instrument for increasing competitiveness, but also as the basic element of a new type of knowledge-based society. Thus, the intellectual property system underlies the development of a modern intellectual economy, and the development of a culture of protection and protection of intellectual property is no less important than the protection of the environment or material property.

In Latvia, the real protection of intellectual property is only beginning to develop, which can be explained by the low legal culture of the Latvian society. Therefore, it seems important to study the experience of other states and carry out explanatory work among representatives of small, medium and large businesses on the protection of intellectual property rights and its effective use in business.

Forming a culture of protecting intellectual property rights, business representatives can get an effective and powerful tool to increase revenues, gain advantages over their competitors, and therefore a stable and solid position in the market. The sphere of intellectual property belongs to the main resources of the state, its scientific and technical potential, which, ultimately, will determine the fate and result of ongoing economic transformations.

The research allows concluding that the ability to determine and establish the value of an intellectual product, including an invention, the conditions for its distribution, effectuation and implementation objectively allows you to equate such a product with a commodity and, therefore, determine the circle of persons possessing the rights of possession, disposal and use of this invention.

The formation of the intellectual property market is currently one of the main directions of development of the Latvian market economy. At a time when all over the world there is an active trade in the results of intellectual activity, and the products of many companies differ only in trademarks, in Latvia this market segment is just beginning to develop.

Indeed many domestic companies still do not pay due attention to work in the field of intellectual property, but, as the experience of the most dynamically developing companies shows, the possession and competent management of a balanced package of intellectual property objects just gives an advantage in the market, limiting competitors' capabilities and, ultimately, providing companies with the opportunity to earn super-profits. This is primarily due to the emerging prospect of using non-monetary property to increase the authorized capital of enterprises and firms, integrate with Russian and foreign partners by creating joint ventures, 
selling licenses, assigning rights or contributing to the authorized capital, and gaining income without being directly involved in production (licensed trade), to limit the capabilities of competitors, etc.

\section{References}

1. Blakeney, M. (2006). Intellectual property rights and global food security. Intellectual Property Rights: Critical Concepts in Law, Vol. 3. London, New York: Routledge, pp.315 - 339.

2. Fawcett, J.J., Torremans, P. (1998). Intellectual Property and Private International Law. Oxford University Press.

3. Maskus, K.E., Penubarti, M. (1995). How trade-related are intellectual property rights? Journal of International Economics, 39, pp.227 - 248. Retrieved from https://www.sciencedirect.com/science/article/abs/pii/0022199695013778

4. $\quad$ Pētersone, Z. (2013). Intelektuālā īpašuma civiltiesiskās aizsardzības līdzeklị. Tiesu namu aǵentūra.

5. Philips, J., Firth, A. (1990). Introduction to Intellectual Property Law. Second edition. London: Butterworths.

6. Rammer, C. (2009). Innovationsverhalten der Unternehmen in Deutschland 2007 Aktuelle Entwicklungen und die Rolle der Finanzierung (Studien zum deutschen Innovationssystem No. 4-2009). Berlin: Expertenkommission Forschung und Innovation (EFI). Retrieved from https://www.econstor.eu/bitstream/10419/ 156518/1/StuDIS_2009-04.pdf

7. Rozenfelds, J. (2004). Intelektuālais īpašums. Rīga: Zvaigzne ABC.

8. WIPO. (2005). The Economic Contribution of Copyright-Based Industries in Latvia. Retrieved from https://www.wipo.int/export/sites/www/copyright/en/ performance/pdf/econ_contribution_cr_lv.pdf

9. WIPO. (2006). Nākotnes izgudrojumi. Ievads patentu zinībās maziem un vidējiem uznēemumiem. Retrieved from https://www.wipo.int/export/sites/www/sme/en/ documents/guides/translation/inventing_future_la.pdf

10. WIPO. (2011). Liec intelektuālajam īpašumam darboties uznēmēju labā. Retrieved from

https://www.wipo.int/export/sites/www/sme/en/documents/guides/translatio n/making_ip_work_for_business_lat.pdf

11. WIPO. (2014). The IP in the service of humanity. Retrieved from https://www.wipo.int/edocs/pubdocs/ru/wipo_pub_1060.pdf 